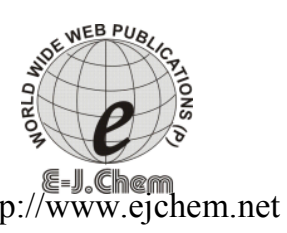

ISSN: 0973-4945; CODEN ECJHAO

E-Journal of Chemistry

http://www.ejchem.net

2012, 9(4), 2185-2190

\title{
Synthesis and Spectroscopic Characterization of Two New Dawson Sandwich Complexes: $\mathrm{Na}_{18}\left[(\mathrm{NaOH})_{2}(\mathrm{VO})_{2}\left(\mathrm{P}_{2} \mathrm{~W}_{15} \mathrm{O}_{56}\right)_{2}\right] \cdot 40 \mathrm{H}_{2} \mathrm{O}$ and $\mathrm{Na}_{18}\left[(\mathrm{NaOH})_{2}(\mathrm{VO})_{2}\left(\mathrm{As}_{2} \mathrm{~W}_{15} \mathrm{O}_{56}\right)_{2}\right] .27 \mathrm{H}_{2} \mathrm{O}$
}

\author{
MOHAMMAD HAKIMI*, MOHAMMAD REZA MOHAMMADI, AND SALMA \\ BEHBOUPOUR
}

Chemistry Department, Payame Noor University, 19395-4697 Tehran, IRAN

hakimi@pnu.ac.ir

Received 01 November 0211; Accepted 07 January 2012

\begin{abstract}
Reaction of the three vacant complex of $a-\left[\mathrm{P}_{2} \mathrm{~W}_{15} \mathrm{O}_{56}\right]^{12-}$ and $a-$ $\left[\mathrm{As}_{2} \mathrm{~W}_{15} \mathrm{O}_{56}\right]^{12-}$ with divalent cation of $\mathrm{VO}^{2+}$ in $1: 1$ mole ratio yields a previously unknown sandwich-type Wells-Dawson complex; $\mathrm{Na}_{18}\left[(\mathrm{NaOH})_{2}(\mathrm{VO})_{2}\left(\mathrm{P}_{2} \mathrm{~W}_{15} \mathrm{O}_{56}\right)_{2}\right] \cdot 40 \mathrm{H}_{2} \mathrm{O}$ (represented as $\left.\mathrm{Na}_{2}(\mathrm{VO})_{2} \mathrm{P}_{4} \mathrm{~W}_{30}\right)$ and $\mathrm{Na}_{18}\left[(\mathrm{NaOH})_{2}(\mathrm{VO})_{2}\left(\mathrm{As}_{2} \mathrm{~W}_{15} \mathrm{O}_{56}\right)_{2}\right] \cdot 27 \mathrm{H}_{2} \mathrm{O}$ (represented as $\left.\mathrm{Na}_{2}(\mathrm{VO})_{2} \mathrm{As}_{4} \mathrm{~W}_{30}\right)$. These complexes contain anions in which two divalent $\mathrm{VO}^{2+}$ cations with two $\mathrm{Na}^{+}$ions are symmetrically sandwiched between two $\alpha-\left[\mathrm{P}_{2} \mathrm{~W}_{15} \mathrm{O}_{56}\right]^{12-}$ or $\alpha-$ $\left[\mathrm{As}_{2} \mathrm{~W}_{15} \mathrm{O}_{56}\right]^{12-}$ groups leading to a "lacunary" sandwich complex. The anion complexes are isolated as sodium salts and characterized by elemental analysis, TGA, IR, ${ }^{31} \mathrm{P}$ NMR and UV-Vis spectroscopy.
\end{abstract}

Keywords: Synthesis, Polyoxometalate, $\mathrm{VO}^{2+}$, Wells-Dawson structure.

\section{Introduction}

Polyoxometalates (POMs) form a distinctive class of inorganic metal-oxygen cluster compounds which is unique in its topological and electronic versatility and useful in fields as diverse as catalysis, analysis, biochemistry, medicine and material Science [1]. The class of POMs has been known for almost 200 years since the first structural details were revealed. Up to now, POMs chemistry continues to be a considerable focus in the ongoing research because large numbers of the novel structures of POMs and their properties [2]. Many of the fundamental properties of POMs that impact their applications, including elemental composition, solubility, redox potential(s), charge density, size, and shape, can be systematically altered to a considerable degree [3]. Within the class of polyoxoanions, those species based on trivacant Wells-Dawson fragments are particularly attractive. The first Wells-Dawson derivatives, $\left[\mathrm{M}_{4}\left(\mathrm{OH}_{2}\right)_{2}\left(\mathrm{P}_{2} \mathrm{~W}_{15} \mathrm{O}_{56}\right)_{2}\right]^{16-}\left(\mathrm{M}=\mathrm{Co}^{2+}, \mathrm{Cu}^{2+}, \mathrm{Zn}^{2+}\right)$ [4] was reported by Finke et al. in 1983. Several years later, Bi et al. described the first arsenic(V) analogues of the Wells-Dawson type, $\left[\mathrm{M}_{4}\left(\mathrm{OH}_{2}\right)_{2}\left(\mathrm{As}_{2} \mathrm{~W}_{15} \mathrm{O}_{56}\right)_{2}\right]^{16-}\left(\mathrm{M}=\mathrm{Mn}^{2+}, \mathrm{Co}^{2+}, \mathrm{Ni}^{2+}\right.$, 
$\left.\mathrm{Cu}^{2+}, \mathrm{Zn}^{2+}, \mathrm{Cd}^{2+}\right)$ [5]. These two families of complexes can be considered as "saturated", as they have in their structure the maximum number of $\mathrm{d}$ metal centers that can be "sandwiched" by the trivacant Wells-Dawson polyoxoanion $\left[\mathrm{X}_{2} \mathrm{~W}_{15} \mathrm{O}_{56}\right]^{12-}(\mathrm{X}=\mathrm{As}$ or P).

The first example of a "unsaturated" sandwich-type species with less than four transition metals was described by Hill et al. [6] The diiron(III)-substituted polyanion $\left[(\mathrm{NaOH})_{2} \mathrm{Fe}_{2}\left(\mathrm{P}_{2} \mathrm{~W}_{15} \mathrm{O}_{56}\right)_{2}\right]^{16-}$ is based on two Wells-Dawson fragments $\left[\mathrm{P}_{2} \mathrm{~W}_{15} \mathrm{O}_{56}\right]^{12-}$ that sandwich a tetranuclear metal cluster, $\left[\mathrm{Fe}_{2} \mathrm{O}_{14}(\mathrm{NaOH})_{2}\right]$, in which the two equivalent interior positions are occupied by $\mathrm{Fe}^{\mathrm{III}}$ centers, and the two equivalent exterior positions are occupied by sodium ions in the solid state.

In this paper the reactions of $\alpha-\left[\mathrm{P}_{2} \mathrm{~W}_{15} \mathrm{O}_{56}\right]^{12-}$ and $\alpha-\left[\mathrm{As}_{2} \mathrm{~W}_{15} \mathrm{O}_{56}\right]^{12-}$ with divalent $\mathrm{VO}^{2+}$ cation which lead to "unsaturated" sandwich-type complexes of the formula $\mathrm{Na}_{18}\left[(\mathrm{NaOH})_{2}(\mathrm{VO})_{2}\left(\mathrm{P}_{2} \mathrm{~W}_{15} \mathrm{O}_{56}\right)_{2}\right] \cdot 40 \mathrm{H}_{2} \mathrm{O}$ and $\mathrm{Na}_{18}\left[(\mathrm{NaOH})_{2}(\mathrm{VO})_{2}\left(\mathrm{As}_{2} \mathrm{~W}_{15} \mathrm{O}_{56}\right)_{2}\right] \cdot 27 \mathrm{H}_{2} \mathrm{O}$ are reported.

\section{Experimental}

\section{Materials and methods}

All reagents were commercially obtained and used without further purification. $\alpha$ $\left[\mathrm{P}_{2} \mathrm{~W}_{18} \mathrm{O}_{62}\right]^{6-}[7], \alpha-\left[\mathrm{P}_{2} \mathrm{~W}_{15} \mathrm{O}_{56}\right]^{12-}[4], \alpha-\left[\mathrm{As}_{2} \mathrm{~W}_{18} \mathrm{O}_{62}\right]^{6-}[8]$ and $\alpha-\left[\mathrm{As}_{2} \mathrm{~W}_{15} \mathrm{O}_{56}\right]^{12-}[5]$ were prepared by the literature methods, and their purity was checked by infrared spectroscopy. $\mathrm{V}, \mathrm{Na}, \mathrm{P}, \mathrm{As}$ and $\mathrm{W}$ analyses were performed by ICP-OES Simultaneous model VISTAPRO. Infrared spectra ( $2 \%$ sample in $\mathrm{KBr}$ ) were recorded on a FT-IR 8400 Shimadzu. 31P NMR spectra were recorded on a FT-NMR model Bruker Brx 500 AVANCE using 85\% $\mathrm{H} 3 \mathrm{PO} 4$ as an external reference. The water contents of the complexes have been determined by Thermo Gravimetric Analysis (TGA) using TGA-50 Shimadzu apparatus. The electronic spectra were recorded on a Shimadzu UV-Vis Spectrophotometer.

Synthesis of $\mathrm{Na}_{18}\left[(\mathrm{NaOH})_{2}(\mathrm{VO})_{2}\left(\mathrm{P}_{2} \mathrm{~W}_{15} \mathrm{O}_{56}\right)_{2}\right] .40 \mathrm{H}_{2} \mathrm{O}$

$\mathrm{VOSO}_{4}(0.25 \mathrm{~g}, 1.0 \mathrm{mmol})$ was dissolved in $60 \mathrm{~mL}$ of a $4 \mathrm{M} \mathrm{NaCl}$ solution with stirring. $\mathrm{Na}_{12} \mathrm{P}_{2} \mathrm{~W}_{15} \mathrm{O}_{56}(4.0 \mathrm{~g}, 1.0 \mathrm{mmol})$ was then added and dissolved by heating and stirring. Any insoluble material was removed by hot filtration. The clear solution was cooled overnight at $5^{\circ} \mathrm{C}$. The dark crystalline solid that formed was collected and dried at room temperature. The yield was $2.60 \mathrm{~g}$ of a dark crystalline solid $(59.22 \%)$.

FT-IR (KBr disc, $\left.c m^{-1}\right): 1087 \mathrm{~s}\left(\mathrm{v}_{\text {as }} \mathrm{P}-\mathrm{Oa}\right), 1010 \mathrm{sh}\left(\mathrm{v}_{\mathrm{as}} \mathrm{P}-\mathrm{Oa}\right), 1041 \mathrm{~m}\left(\mathrm{v}_{\mathrm{as}} \mathrm{P}-\mathrm{O}\right), 935 \mathrm{~s}\left(\mathrm{v}_{\mathrm{as}}\right.$ $\mathrm{W}-\mathrm{Od}), 825 \mathrm{~s}\left(v_{\text {as }} \mathrm{W}-\mathrm{Ob}-\mathrm{W}\right), 723 \mathrm{~s}\left(v_{\mathrm{as}} \mathrm{W}-\mathrm{Oc}-\mathrm{W}\right)$.

${ }^{31} \mathrm{P} N M R\left(500 \mathrm{MHz}, \mathrm{D}_{2} \mathrm{O}\right)$ : $\delta-15.0(\mathrm{~s}, \mathrm{P}(2)) \mathrm{ppm} ; \delta 72.6(\mathrm{~b}, \mathrm{P}(1)) \mathrm{ppm}$.

Elemental Analysis: $\mathrm{Na}_{18}\left[(\mathrm{NaOH})_{2}(\mathrm{VO})_{2}\left(\mathrm{P}_{2} \mathrm{~W}_{15} \mathrm{O}_{56}\right)_{2}\right] .40 \mathrm{H}_{2} \mathrm{O}\left(8770.94\right.$ g.mol $\left.{ }^{-1}\right) ; \mathrm{Na} 4.68$

(Calcd. 5.51); P 1.27 (1.41); V 1.22 (1.16); W 63.31 (62.90).

Electronic Spectrum $\left(\mathrm{H}_{2} \mathrm{O}, \lambda_{\max } \mathrm{nm}\right) / \varepsilon\left(\right.$ L.mol $\left.\left.^{-1} . \mathrm{cm}^{-1}\right)\right): 466 / 2750(\mathrm{O} \rightarrow \mathrm{V}), 634 / 943.75(\mathrm{~d}-\mathrm{d})$. Synthesis of $\mathrm{Na}_{18}\left[(\mathrm{NaOH})_{2}(\mathrm{VO})_{2}\left(\mathrm{As}_{2} \mathrm{~W}_{15} \mathrm{O}_{56}\right)_{2}\right] \cdot 27 \mathrm{H}_{2} \mathrm{O}$

$\mathrm{VOSO}_{4}(0.25 \mathrm{~g}, 1.0 \mathrm{mmol})$ was dissolved in $40 \mathrm{~mL}$ of a $3 \mathrm{M} \mathrm{NaCl}$ solution with stirring. $\mathrm{Na}_{12} \mathrm{As}_{2} \mathrm{~W}_{15} \mathrm{O}_{56}$ (4.46 g, $1.0 \mathrm{mmol}$ ) was then added and dissolved by heating and stirring.

Any insoluble material was removed by hot filtration. The clear solution was cooled overnight at $5^{\circ} \mathrm{C}$. The dark crystalline solid that formed was collected and dried at room temperature. The yield was $2.42 \mathrm{~g}$ of a dark crystalline solid $(55.49 \%)$.

FT-IR $\left(\mathrm{KBr}\right.$ disc, $\left.\mathrm{cm}^{-1}\right): 948 \mathrm{~s}\left(\mathrm{v}_{\mathrm{as}} \mathrm{W}-\mathrm{Od}\right), 871 \mathrm{~m}\left(\mathrm{v}_{\mathrm{as}} \mathrm{W}-\mathrm{Ob}-\mathrm{W}\right), 817 \mathrm{~m}\left(\mathrm{v}_{\mathrm{as}} \mathrm{W}-\mathrm{Ob}-\mathrm{W}\right), 709$ $\mathrm{s}\left(v_{\mathrm{as}} \mathrm{W}-\mathrm{Oc}-\mathrm{W}\right)$.

Elemental Analysis: $\mathrm{Na}_{18}\left[(\mathrm{NaOH})_{2}(\mathrm{VO})_{2}\left(\mathrm{As}_{2} \mathrm{~W}_{15} \mathrm{O}_{56}\right)_{2}\right] .27 \mathrm{H}_{2} \mathrm{O}\left(8712.59\right.$ g.mol $\left.{ }^{-1}\right) ; \mathrm{Na} 5.58$ (Calcd.5.54); As 3.3 (3.44); V 1.86(1.17); W 63.1 (63.32).

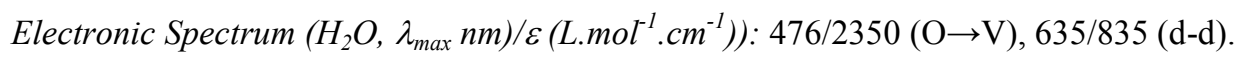




\section{Result and Discussion}

$\mathrm{Na}_{18}\left[(\mathrm{NaOH})_{2}(\mathrm{VO})_{2}\left(\mathrm{P}_{2} \mathrm{~W}_{15} \mathrm{O}_{56}\right)_{2}\right] \cdot 40 \mathrm{H}_{2} \mathrm{O}$

The molecular formula has been determined by elemental analysis and TGA. The elemental analysis for $\mathrm{Na}, \mathrm{P}, \mathrm{W}$ and $\mathrm{V}$ establishes the empirical formula as $\left[\mathrm{Na}_{10} \mathrm{P}_{2} \mathrm{~W}_{15}(\mathrm{VO}) \mathrm{O}_{56}\right]_{\mathrm{x}}$. The TG curve of the title compound shows weight loss processes in the range of $25-200^{\circ} \mathrm{C}$, giving a total loss of $8.141 \%$ of its initial weight, which corresponds to the release of 40 hydration water molecules.

\section{IR Characterization}

The IR spectra of $\mathrm{Na}_{2}(\mathrm{VO})_{2} \mathrm{P}_{4} \mathrm{~W}_{30}$ is shown in Figure 1. Except the $\mathrm{W}-\mathrm{O}$ or $\mathrm{W}-\mathrm{O}-\mathrm{W}$ bands which appear at low wave numbers $\left(<1000 \mathrm{~cm}^{-1}\right)$, IR spectra of phosphorus centered polyoxotungstates are characterized by well separated $\mathrm{P}-\mathrm{O}$ stretching vibrations which are observed between 1200 and $1000 \mathrm{~cm}^{-1}$.

The vibration modes of the unperturbed $\mathrm{PW}_{9}$ moiety are nearly invariant, at $1087 \mathrm{~cm}^{-1}$ (strong) and $1010 \mathrm{~cm}^{-1}$ (low). For the perturbed subunit $\mathrm{PW}_{6}$, the number of IR absorption bands and their position depend on the interaction of the addenda atoms with the free oxygen $\left(\mathrm{O}_{\text {ter }}\right)$ of the phosphate group. Hence, the high-wave number band of $\mathrm{P}_{2} \mathrm{~W}_{15}$ at 1130 $\mathrm{cm}^{-1}$, which can be ascribed to $\mathrm{v}\left(\mathrm{P}-\mathrm{O}_{\text {ter }}\right)$, moves to lower frequency in the sandwich complexes where the $\mathrm{P}-\mathrm{O}$ bond has lost its double-bond character; it corresponds to the medium-intensity band which appears between the $\mathrm{PW}_{9}$ bands, at $1041 \mathrm{~cm}^{-1}$ [9].

The $v_{\text {as }}(\mathrm{W}=\mathrm{Od})$ vibration band is broader in the complexes spectra than the corresponding band in the ligand spectra because of its superposition with the stretching vibration $v_{\text {as }}$ $\operatorname{as}(\mathrm{V}=\mathrm{O})[10]$.

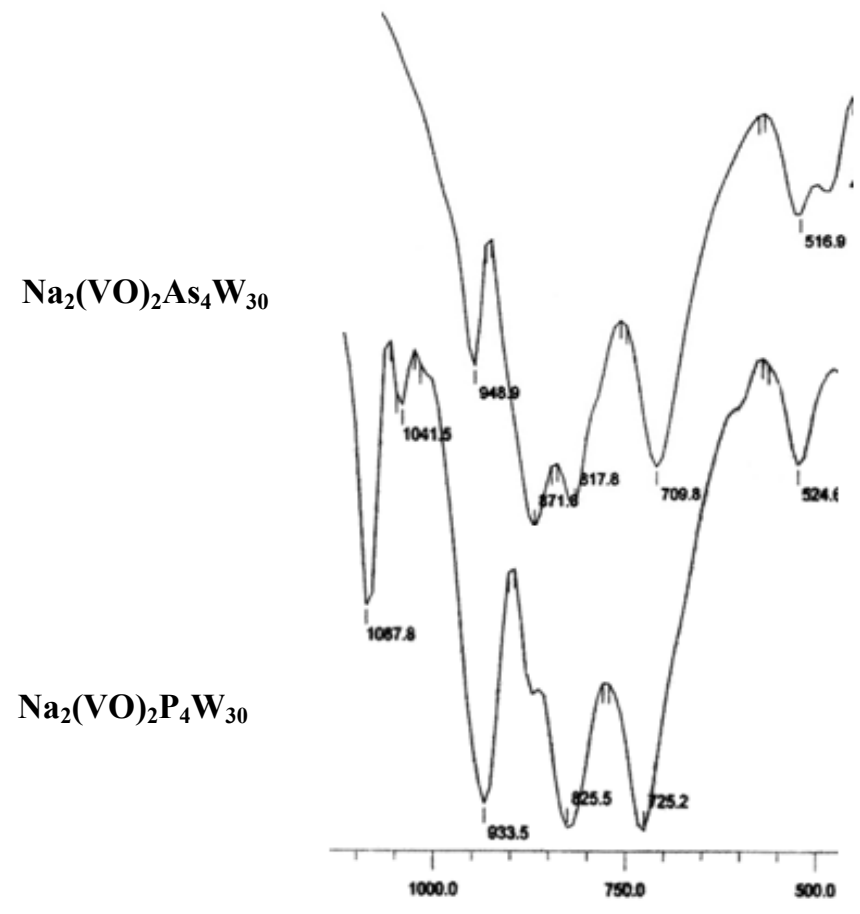

Wave number

Figure 1. IR spectrum of $\mathrm{Na}_{2}(\mathrm{VO})_{2} \mathrm{P}_{4} \mathrm{~W}_{30}$ and $\mathrm{Na}_{2}(\mathrm{VO})_{2} \mathrm{As}_{4} \mathrm{~W}_{30}$. 


\section{${ }^{31}$ P NMR Characterization}

The ${ }^{31} \mathrm{P}$ NMR spectrum of a sandwich complex may present either four or two resonances depending on the symmetry of the framework; in symmetrical complexes $\left(\mathrm{C}_{2} \mathrm{~h}\right.$ symmetry) the two $\mathrm{P}_{2} \mathrm{~W}_{15}$ moieties are equivalent and two bands at most can be observed.

As it is usual for such paramagnetic sandwich complexes, two markedly different types of ${ }^{31} \mathrm{P}$ resonances are observed (Figure 2$)$ : the $\mathrm{P}(2)$ atoms in the $\left\{\mathrm{PW}_{9}\right\}$ subunits, far from the paramagnetic centers, give relatively narrow line at -15.0 ppm, while the $\mathrm{P}(1)$ atoms, close to the TM sheet, give broad and deshielded signal (72.6 ppm) [11].

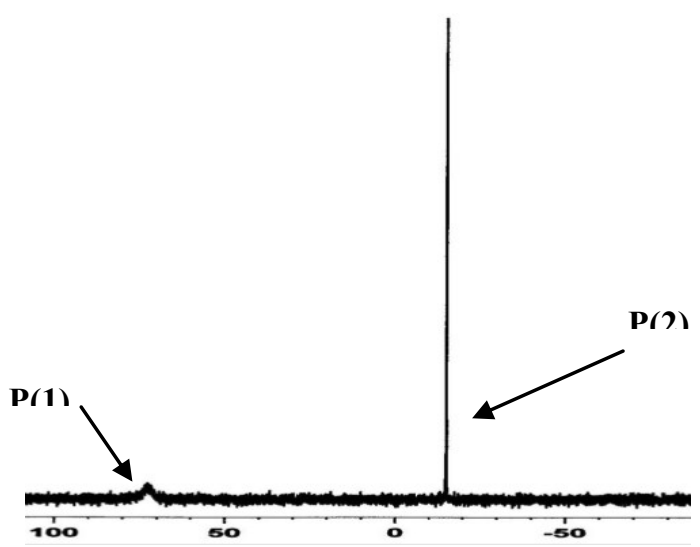

Figure 2. ${ }^{31} \mathrm{P}$ NMR spectrum of $\mathrm{Na}_{2}(\mathrm{VO})_{2} \mathrm{P}_{4} \mathrm{~W}_{30}$.

Electronic Spectrum

The visible electronic spectrum of the complex (Figure 3) show a relative stronger absorption at $466 \mathrm{~nm}$ and a band with a shoulder at $634 \mathrm{~nm}$. The strong absorptions correspond to the $\mathrm{V}^{\mathrm{IV}}$ charge transfer transitions [12]. The band for $\mathrm{V}^{\mathrm{IV}}$ ion d-d transitions is observed at $634 \mathrm{~nm}[13]$.

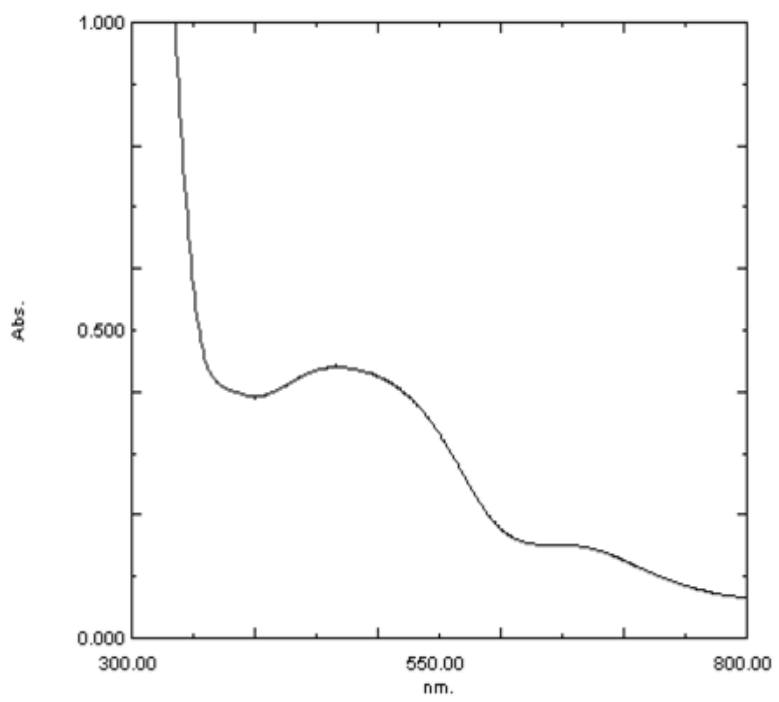

Figure 3. UV-Vis spectrum of $\mathrm{Na}_{2}(\mathrm{VO})_{2} \mathrm{P}_{4} \mathrm{~W}_{30}$. 
The molecular formula has been determined by elemental analysis and TGA. The elemental analysis for $\mathrm{Na}, \mathrm{As}, \mathrm{W}$ and $\mathrm{V}$ establishes the empirical formula as $\left[\mathrm{Na}_{10} \mathrm{As}_{2} \mathrm{~W}_{15}\left(\mathrm{VO} \mathrm{O}_{56}\right] \mathrm{x}\right.$. The TG curve of the title compound shows weight loss processes in the range of $25-200^{\circ} \mathrm{C}$, giving a total loss of $5.652 \%$ of its initial weight, which corresponds to the release of 27 hydration water molecules.

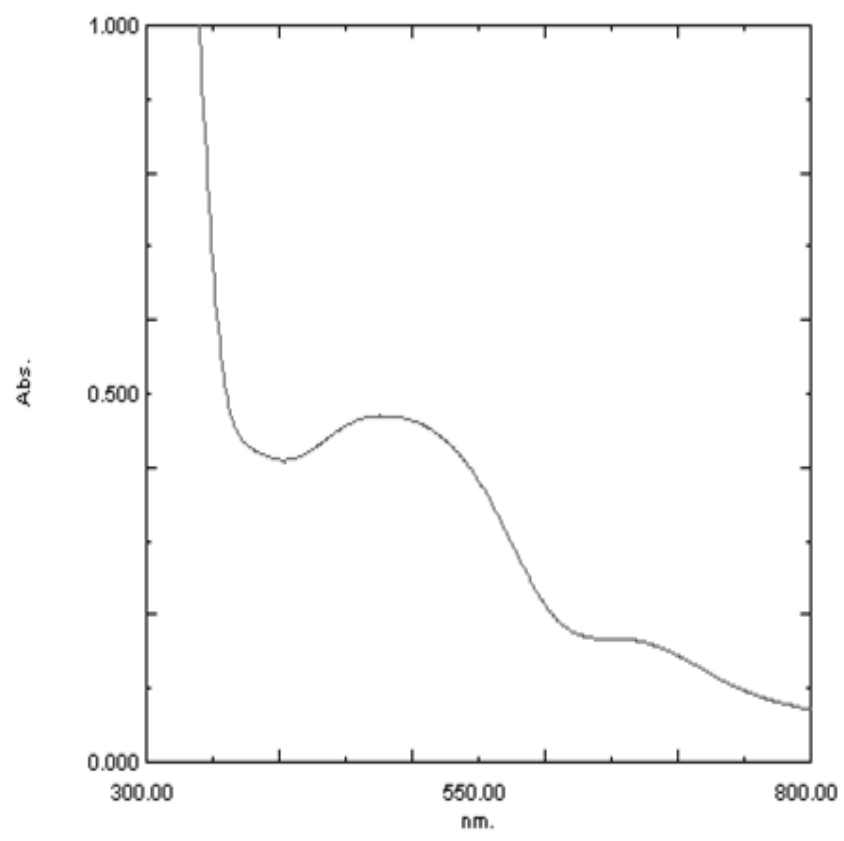

Figure 4. UV-Vis spectrum of $\mathrm{Na}_{2}(\mathrm{VO})_{2} \mathrm{As}_{4} \mathrm{~W}_{30}$.

\section{IR Characterization}

As expected, the IR spectra of the sandwich-type complex is very similar to that of the trivacant lacunary $\alpha-\left[\mathrm{As}_{2} \mathrm{~W}_{15} \mathrm{O}_{56}\right]^{12-}$, except for the splitting of the asymmetry stretching vibration of $\mathrm{W}-\mathrm{Oc}-\mathrm{W}$ (Oc is the edge sharing oxygen) (Figure. 1). This is attributed to the presence of the divalent cations (directly bound to the terminal oxygen of an edge shared pair of WO6) [14].Also all of the characteristic vibrational frequencies decrease compared with those of [As2W18O62]6-, which is attributed to the increase of the negative charges of the anions [5]. The $v_{\text {as }}(\mathrm{W}=\mathrm{Od})$ vibration band is broader in the complexes spectra than the corresponding band in the ligand spectra because of its superposition with the stretching vibration $v_{\mathrm{as}}(\mathrm{V}=\mathrm{O})[10]$.

\section{Electronic Spectrum}

The visible electronic spectra of the complex (Figure 4) show a relative stronger absorption at $476 \mathrm{~nm}$ and a band with a shoulder at $635 \mathrm{~nm}$. The strong absorptions correspond to the $\mathrm{V}^{\mathrm{IV}}$ charge transfer transitions [12]. The band for $\mathrm{V}^{\mathrm{IV}}$ ion d-d transitions is observed at 635 $\mathrm{nm}[13]$. 


\section{References}

1. L. Ruhlmann, J. Canny, J. Vaissermann, René Thouveno, Dalton Trans., 2004, 794.

2. M.T. Pope, Heteropoly and Isopoly Oxometalates, Springer-Verlag, New York, 1983.

3. I. M. Mbomekalle, R. Cao, K. I. Hardcastle, C. L. Hill, M. Ammam, B. Keita, L. Nadjo, T. M. Anderson, C. R. Chimie. 2005, 8, 1077.

4. R. G. Finke, M. W. Droege, P. J. Domaille, Inorg. Chem. 1987, 26, 3886.

5. L. H. Bi, E.-B. Wang, J. Peng, R. D. Huang, L. Xu, C. W. Hu, Inorg. Chem. 2000 , 39, 671.

6. X. Zhang, T. M. Anderson, Q. Chen, C. L. Hill, Inorg. Chem.2001, 40, 418.

7. I. M. Mbomekalle, Y. W. Lu, B. Keita, L. Nadjo, Inorg. Chem. Commun., 2004, 7, 86.

8. I. M. Mbomekalle, B. Keita, L. Nadjo, R. Contant, N. Belai, M. T. Pope, Inorganica Chimica Acta, 2003, 342, 219.

9. L. Ruhlmann, J. Canny, R. Contant, R. Thouvenot, Inorg. Chem., 2002, 41, 3811.

10. N. Joo, M. Hossu, D. Rusu, A. Marcu, M. Rusu, C. Pasca, L. David, Acta Chim. Slov. 2007, 54, 749.

11. T. L. Jorris, M. Kozik, N. Casañ-Pastor, P. J. Domail, R. G. Fink, W. K. Miller, L. C. W. Baker, J. Am. Chem. Soc. 1987, 109, 7402.

12. D. P. Smith, H. So, J. Bender, M. T. Pope, Inorg. Chem. 1973, 12, 685.

13. N. Joo, M. Hossu, D. Rusu, A. Marcu, M. Rusu, C. Pasca, L. David, Acta Chim. Slov, 2007, 54, 749.

14. R. Khoshnavazi, A. Salimi, A. G. moaser, Polyhedron, 2008, 27, 1303. 


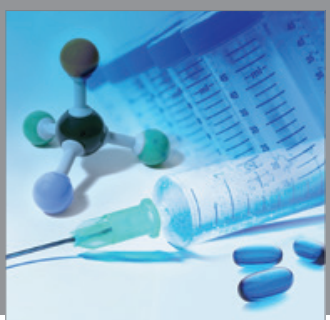

International Journal of

Medicinal Chemistry

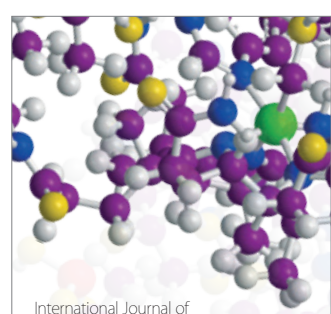

Carbohydrate Chemistry

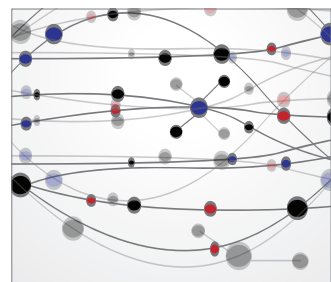

The Scientific World Journal
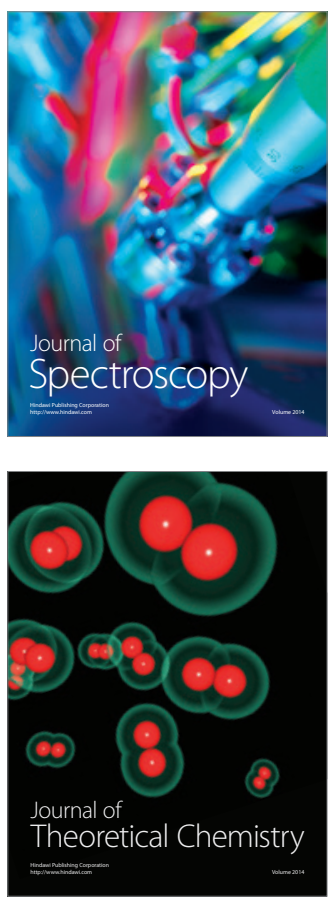
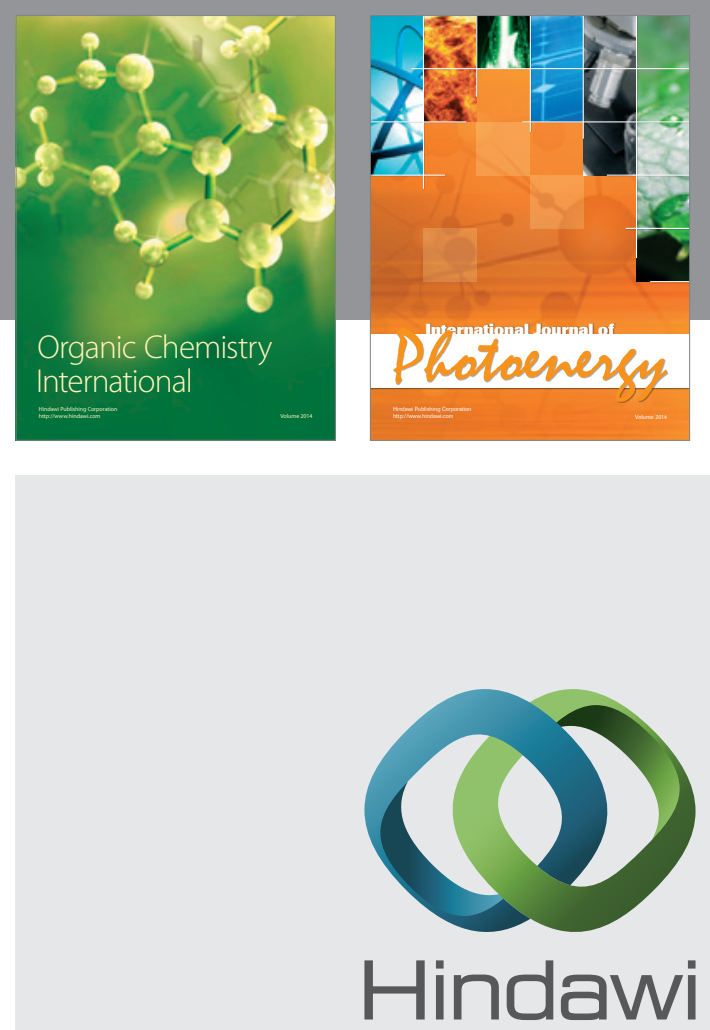

Submit your manuscripts at

http://www.hindawi.com
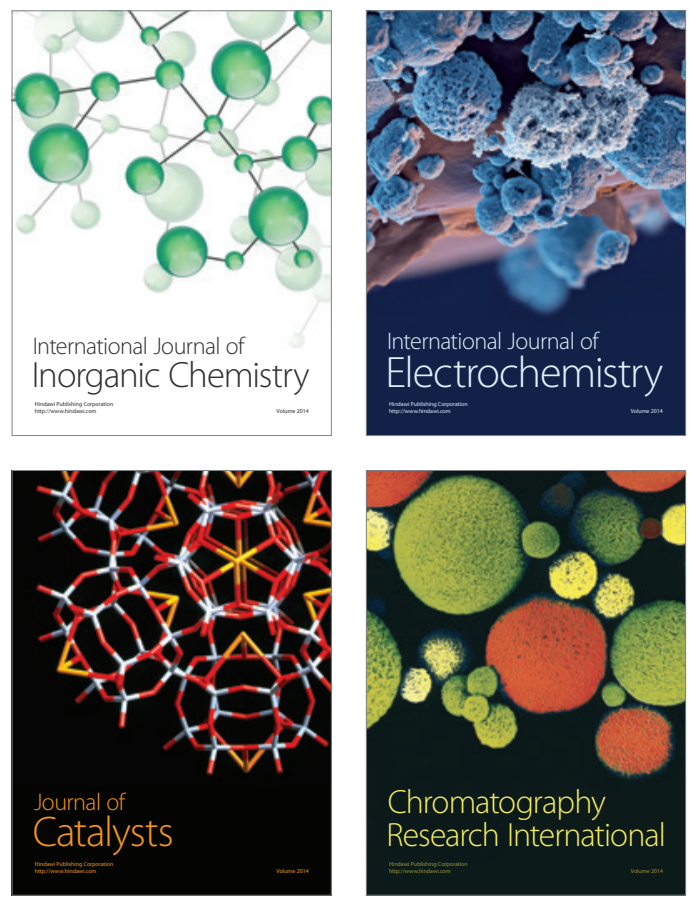
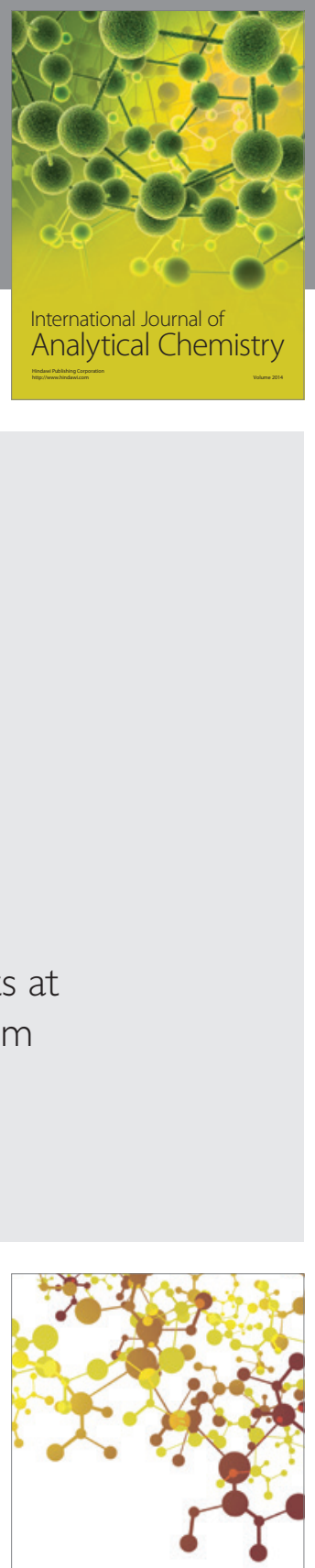

Journal of

Applied Chemistry
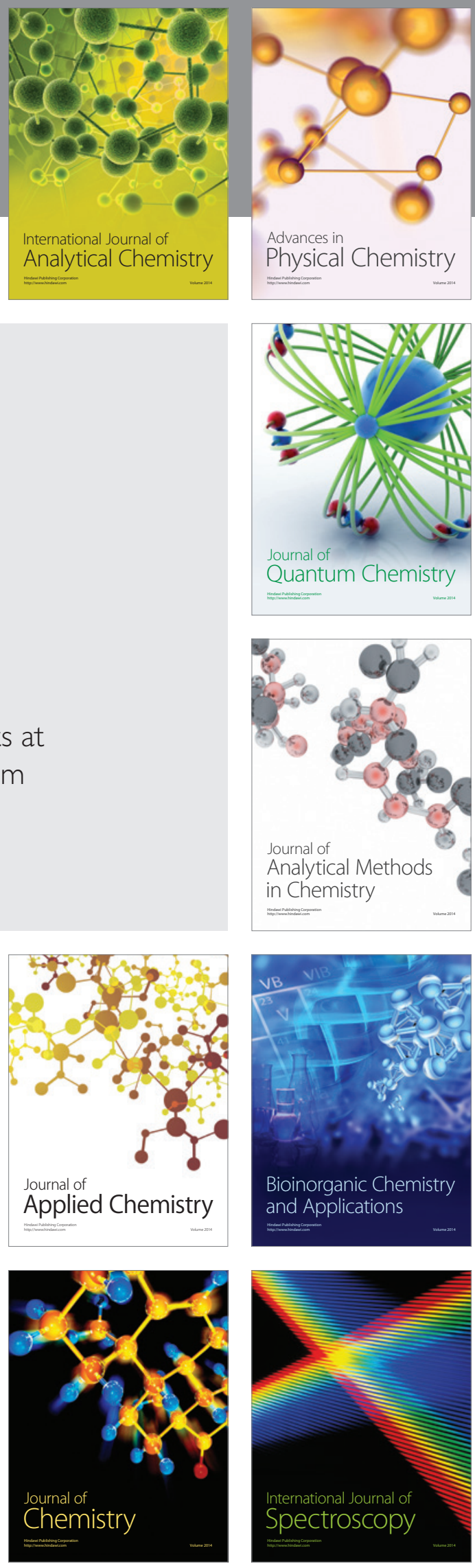